\title{
Contemporising the Topos of Shakespearean Dramas: A Comparative (Re)Reading of Memory, Masculinity and Vengeance with special reference to William Shakespeare's Tragedies and History Plays
}

\section{Rahul Kar 1}

${ }^{1}$ Assistant Teacher of a Govt. School, An M.A in English Literature from University of North Bengal, West Bengal, India. Email id-thisisrahulapd@gmail.com | Orcid ID: 0000-0001-7362-8788

\section{Sangeeta Saha ${ }^{2}$}

${ }^{2}$ Assistant Teacher of a Govt. School, An M.A in English Literature from University of North Bengal, West Bengal, India. Email id.-sohasaha3010@gmail.com | Orcid ID: 0000-0002-7362-8443

\begin{abstract}
This present paper anticipates several prevalent topos of Shakespearean plays especially in tragedies and history plays where both the authors endeavor to (re)vivify issues like virility, madness, retaliation and memory. The play Henry $V$ epitomizes undaunted mental or moral qualities and upstanding ardor and comes into the view of himself, a machinery of careful consideration of what will be necessary or may happen in the future. Together the authors zero in on how the abstractions of these terms facetiously, had sown in the faculty of sensibility, cognition, action of meditating and in the performance of putting something into operation after exquisite synthesis of the playwright so that he could so effortlessly orchestrate profligacy of humans for the characters to become destiny. Macbeth, Hamlet, Titus and so on are no malevolent rather one of the primordial sins among seven that overmatches the gracious traits overarchingly and get at conclusive decimation. The paper also homes in on deciphering the implicit hortative exhortation for all to chase yea and nay, disequilibrium and unreasonableness on no account so that the human psyches shall hold out subsist unblemished forevermore.
\end{abstract}

Keywords: Madness, Masculinity, Vengeance, Mnemonic, Drama, Tragedy, History Plays.

\section{INTRODUCTION}

Every knowledgeable assembled spectator or listener will succeed to give reaction to a fanciful spectacle (Chorus draws an illustration of a land on the eve of an exotic adventuresome exploration) in Act 2 of Henry $V$ to so high a degree: "Now all the youth of England are on fire,/ And silken dalliance in the wardrobe lies; / Now thrive on armourers, and honour's thought/ Reigns solely in the 
breast of every man." (Henry V, 1-4). The mentioning of 'honour's thought' with reference to the Chorus in Act V to the Earl of Essex's much expected coming-back from Ireland - ought to have tingled kind of amazingly impudent indorsation of the place the Earl belonged to and the entirety he halted for. In lieu of the depiction of Chorus better than the original, rather utopian, of the flaming juvenility of England, we have been provided with ordinary truth of battlers, fighting or quarrelling in a rough or noisy way, disintegrated commitments, and peevish lewdness and bloodshedding.

The event subordinate to the main events of the play Henry $V$ appears in a similar way, a burlesque of the valorous principal events of the drama. J.H. Walter was of the opinion that Henry consolidates the disposition and execution of a person, typically, a man who is admired or idealized, for courage, outstanding achievements or noble qualities, typically derived from the ancient oral tradition of, relating to, or characteristic of an epic or epics with the righteous attributes of a Dutch humanist and theologian who was the leading Renaissance scholar of Northern Europe, Erasmus' son of a monarch, relating to or professing Christianity or its teachings. Henry becomes apparent to have banked on accurately describing or predicting what will happen in the future, royal prospect and to have discerned himself as an apparatus of forethought. Shakespeare's Henry possesses undue, straightforward earnestness that is innate of the proselyte of relating to or believing in a religion and one who takes a look at himself as a device of the testament of Paradise.

Henry $v$ and Troilus and Cressida are highly relevant and incidental dramas, having a strong patriotic feelings or consciousness of laurels, especially a belief in the superiority of one's own country over others. Incompatible to Hamlet in the drama Hamlet whose response to a solicitation to homage, relating to the line of kings, is a mushy proposition of vengeance, Henry continues to be gentle or soothing, diligently and calmly causing to remember the moot of the essentiality to ready up not just for an alien exploration but also for the likelihood of an invasion off Scotland. Adherence to the dictation of the phenomena of the physical world, opines Canterbury, is the cotter to convivial conformity, as the individuals of a honeycomb act simultaneously at one place under the command of the monarch, so nationwide prevalence is determined by each individual of a community performing for the demand of universal prosperity. Canterbury's simple story , used to illustrate a moral or spiritual lesson is intended as an elucidation of the common or usual ethics that Exeter justly had narrated in the book and further went on, "Government through high and low and lower, / Put into parts, doth keep in one consent,/Congreeing in a full and natural close,/Like music." (Henry V) Thus conformity or congruence that is tuneful or melodious becomes crucially important figure of speech, deals with comparison, in diplomatic logical arguments in this age.

Following mores, masculinity is ever related to bestiality, foray, and subjugation. In The tragedy of Macbeth, in spite of being a commander-in-chief, Macbeth is distinguished as an extortioner and pliable spouse and is brought under control by his haughty lady. This play neatly debunks that similar idiosyncratic features as leery and the proficiency to get at one's target by hook or by crook - the distinctive attributes peculiarly and banally connected to women- be also come under the 
group of virility. The identity of Lady Macbeth with her inclination to the conception of turning out to be the Lady of the Lord of Scotland by revealing as idée fixe in this drama provides the readers with cotter to perceiving dame masculinity, having "acute mind, strong will, and a beautiful body...full of animation and grace" ( Munro 30-36) , loaded with malice, avidity and disdain and her longing for the act of making herself masculine by disowning herself of the pistillate virtues in the lines, "Come, you spirits/ That tend on mortal thoughts! Unsex me here, / And fill me from the crown to the toe top full Of direst cruelty." (Howell 38-41) negates the rules of nature and thus brings conclusive doom. Lady takes a look at herself as a catalyzer of convivial and diplomatic transformation in addition to that the sole origin of masculine might and thus she impersonates many masculine attributes, Macbeth was devoid of. Assassinating the Monarch, Macbeth transgressed the law of conduct pertaining to Chivalry that redressed a man to follow particular models of demeanor.

The bystanders', during the time of queen Elizabeth, needs were concentrated with the portrayal of vengeance inwardly of the play, Hamlet wherein at that place will be haggard righteousness, the obligation of vengeance ought to be deliberated as a sacred responsibility over the subsequent dynast. The drama rambles round the notions of vengeance, retribution and requital. It is play of retribution within retribution, vengeance within vengeance having lengthy and funebrial velitation between Hamlet and Claudius and in the sub-plot of Laertes' taking revenge of his father Polonius' slaughter. A.C. Bradley rightly opined about the spooky manifestation in Hamlet, "The ghost in Hamlet strikes the imagination as the representation of the hidden power, the messenger of the divine justice upon the expatiation of the offences." Soon after being informed by the ghosts about his father's assassinator, the germs of bloody affray, incontinence, liquefaction and death, Hamlet said expressing the gusto of ascertainment for taking retaliation, "And so I am revenged. That would be scanned: a villain kills my father, and for that, I his sole son, this same villain send to heaven." (Hamlet, Act III, Scene iii) With each case of murder, the play insinuates objectives of reprisal like the brutal assassination of Hamlet's father by Claudius, then death of Queen Gertrude having taken the venomed goblet and finally Claudius, Laertes, Hamlet all three died with basilisk scimitar. Hamlet pledged a drama within the drama Hamlet, 'The Murder of Gonzago' and about the play he said, "The play's the thing / Wherein I will catch the conscience of the King." (Hamlet, Act II, Scene ii). The Norwegian son of the King, Fortinbras intentionally encroached into the periphery of Denmark with a purpose of taking vengeance of the slaughter of his father. For executing the ticklish and dodgy piece of work of vengeance or retaliation the prefect got emaciated in his memory besides that he was getting troubled with the portent of irresolution and dalliance, as mirrored in his celebrated soliloquy, "To be or not be, that is the question: whether 'tis nobler in the mind to suffer the slings and arrows of outrageous fortune or to take arms against a sea of trouble and by opposing end them." ( Hamlet, Act III, Scene i).

Shakespeare puts forward the characters of Ophelia and King Lear whose anamneses are evidently crumbled up by frenzy besides that Shakespeare brings forth the characters of Edgar and Hamlet who palter rabidity and whose anamneses one daresays, lie unimpaired. Memory waits upon the sensorial genie and wisdom by hitting off ceaselessly in the direction of usual or trite intuition the structures that are delivered to the direction of the custody of her. The 
dissimilation between the substantive and pretended inebriations among these characters disclose not just by what means a Simonidean anamnesis system grounded on conformations within microcosm and macrocosm has received radix but at the same time how by holding on an intercessor sequencing position in a demicosm, a foundation for terrestrial or mortal ability to make out, is constructed.

The Renaissance received as patrimony from ancient ages an intricate order of causes for frenzy and as Michel Foucault has properly spotted out, by the continued progress of existence that writings like Praise of Folly (1509) by Erasmus started to be evident, the individualistic temperament of neurosis appears to attain a foundation. Plato talks in Phaedrus about four variants of "divine madness", thinking each as a "blessing" that arrives off distant and is governed by diverse divinities like Apollo oversees madness accurately describing or predicting what will happen in the future, Dionysus supervises ceremonial madness and Eros and Aphrodite take care of erogenous madness. Shakespeare's adjoining of madness or insanity in King Lear and Hamlet to definite performances of language might have conveyance in addition on different propensities as perfectly seen by Russell Fraser in advance of seventeenth centenary, in The Language of Adam ( 1977) he observed "the forging of an exact correspondence" at the outset of century " between names and things becomes a matter of impatient concern." (Fraser, 1977)

Madness detruncates memory's coalescence with both the sensorial psyche and individual's desire. In Hamlet Ophelia intends to disclose and therefore fails to rake up structure. In opposition to Hamlet's "Words, words, words" ( Act II , Scene ii) Ophelia's terms have " some frame" ( Act III , Scene ii), descanting "winks and nods and gestures" cite the manifestation that "there might be thought ,/ Though nothing sure." ( Hamlet, Act IV, Scene v). Afterwards in the same scene vouching Ophelia's frantic conduct, the King accentuates, "Poor Ophelia / Divided from herself (stands for memory) and her fair judgement."(Hamlet). Listening Ophelia's attaching of rosemary with recollection and pansies with cogitation, Laertes looks at fission and obversion as a perusal in madness and remarks that "thoughts and remembrance [are] fitted." (Hamlet, Act IV, Scene v).

Memory in both its common place and synthetic compositions arrives to comprise one of the egregious affairs of the drama Hamlet- pragmatic and private regularity. In community and in role, memory arbitrates obliquely through rules of action or else straight way through sagacity between sounds and themes and preceding and succeeding, supplying each with comprehensibility. Anamnesis is the central to lead-off parley of Claudius, decisive demand of Fortinbras to govern, commitment of Ophelia to Polonius and Hamlet's league together with the phantom and thus arranged to have performed a play-within-a-play for mnemonic contrivance. But unlike Hamlet, memory does not intercedes between speech and conduct in the case of King Lear. Lear's speech turns out to be as "empty" of terrestrial upshots and as sequestrating as Ophelia's. Lear's abnegation of governance is an untimely retractation of to the reminiscence of an innocent respite outside of sceptered obligation. Afterwards the staving of Goneril and Regan, Lear retains recapitulating psychically to a period when he deliberated it governable. As in Hamlet, Shakespeare appears to insinuate with the melodies of Lear that spurious memory thwarts definite verities of frenzy but in coherence with the extrapolating temperament of dialect, the volume of the practices of retention in the play is share of teaching or offering commandments. 
In its dealing of rabidity and remembrance, King Lear exhibits nothing remarkable variation in the objectives of drama that the playwright discloses in Hamlet. Guileless are the primodial responses that the fizzles of desire propagates and Lear figures out that he himself is , More sinn'd against than sinning." (King Lear, Act iii, Scene ii) and Gloucester too that, "As flies to the wanton boys / Are we to the Gods/ They kill us for their sport." (King Lear, Act Iv Scene i)

The affair of vengeance is evidently delineated in the drama Titus Andronicus by Shakespeare in projection of the disposition of Aaron, a rapscallion one, governed by vengeance having no such supporting causes that make him pursue such, : Vengeance is in my heart, death in my hand ,/ Blood and revenge are hammering in my head." (Titus Andronicus, Act II, Scene iii) from Tamora's side and had retaliation upon Titus because of Tamora. Aaron's alignment with Tamora unfolds another angle of vengeance in this drama: "To villainy and vengeance consecrate,/Will we acquaint withal what we intend," ( Titus Andronicus, Act II Scene i).

\section{CONCLUSION}

The prefect Titus' persuasion of vengeance, provoked and wielded by Lavinia with her drawing the names of the bunglers on the grit stands just when he found the detruncated heads of his two sons: "Then which ways shall I find Revenger's cave,/ For those two heads do seem to speak to me / And threat me, I shall never come to blish,/ Till all these mischiefs be returne'd again,/ even in their throats that hath committed them." (Titus Andronicus,Act III , Scene i). Revenge, vengeance or retaliation has evermore been one of mortal's vile or contemptible inducements and will ever continue to be an ordinary ecumenic measure of propulsion in all respects of time. The dramaturgists pertained to the age of queen Elizabeth inclusive of William Shakespeare in one avenue or the other, encountered the vengeance affair to educate all never to ensure their impetuosity because impetus and performances linked to retribution are neither restrainable nor suppressible, and to get around retributory punishment that beefs up individual's discommodity and hardship. Vengeance deals and acts as an intermediary deputationist and a token of the transfiguration of the disposition of the figure. The payoffs of vengeance and bloodshed on individual's disposition are symptoms that kindness, compassion, grace and love can be tainted polluted and vitiated and metamorphosed by sinister knitting malevolent that causes to perform or execute or direct also to the malformation of mortal subsistence.

\section{References}

"King Lear By William Shakespeare - Free PDF Ebook." Williamshakespeare.net. N.p., 2021. Web. 7 Mar. 2021 . <https://www.williamshakespeare.net/ebook-king-lear.jsp>.

"The Bodleian First Folio." Firstfolio.bodleian.ox.ac.uk. N.p., 2021. Web. 7 Jan. 2021 $<$ http:// firstfolio.bodleian.ox.ac.uk/>.

"William Shakespeare: 20 Facts, 37 Plays, 375 Poems, 100 Quotes \& Bio." Williamshakespeare.net. N.p., 2021. Web. 16 Mar. 2021 . <https://www.williamshakespeare.net/ebook-hamlet.js>. 
Allmand, Christopher T. Henry V. New Haven: Yale Univ. Press, 1997. Print.

Amir, Ala Dhafir, "The Theme of Revenge in William Shakespeare's Titus Andronicus", Journal of the College of arts. University of Barsah, (57), 2011.

Antinora, Sarah. "“Eliminating The Female": The Problematics Of The State And Gender In Macbeth." Feminist Studies in English Literature 21.3 (2013): 177-204. Web. 7 Feb. 2021.

Bradley, Andrew Cecil. Shakespearean Tragedy. Harmondsworth: Penguin, 1991. Print.

Camden, Carroll, "On Ophelia's Madness",in Shakespeare 400, ed. James G. McManaway, New York: Holt, Rinehart and Winston, 1964.

Clemen, Woolfgang, The Development of Shakespeare's Imagery. London: Methuen, 1977.

Danby, John F., Shakespeare's Doctrine of Nature : A study of 'King Lear'. London: Faber \& Faber, 1961, pp 81101.

Dent, Arthur. The Ruin Of Rome: Or, An Exposition Upon The Whole Revelation. ... By The Rev. Arthur Dent, ... To Which Is Added, An Epitome Of The Rev. Mr. Brightman's Exposition Upon The Revelation. London: T. Kelly, 1828. Print.

Eliot, T.S., "Hamlet and His Problems", Selected Essays. New York: Harcourt, Brace, and World, 1960.

Evans, G. Blakemore, The Riverside Shakespeare. Boston: Houghton Miffin,1974.

Feather, J, and C Thomas. Violent Masculinities. New York: Palgrave, Macmillan, 2013. Print.

Ferdous, Mafruha. "The Values Of Masculinity In William Shakespeare'S Macbeth." N.p., 2017. Web. 7 Jan. 2021 . <https://www.journals.aiac.org.au/index.php/alls/article/view/3313>.

Foucault, Michel, Madness and Civilisation. New York: Vintage, 1973, p.4.

Fraser, Russell, The Language of Adam. New York: Columbia University Press, 1977, pp. 13-14,18,40,155.

Geoffrey, and Wright. The Historia Regum Britannie of Geoffrey of Manmouth. UK: Boydell \& Brewer Limited, 2001.Print.

Goodyere, Henry, James Croston, and Henry Green. The Mirrour Of Maiestie: Or The Badges Of Honovr Conceitedly Emblazoned. Manchester: Bros., 1870. Print.

Greenblatt, Stephen. Shakespearean Negotiations. Berkeley: Univ. of California Press, 2012. Print.

Harriss, G. L. Henry V. Oxford [Oxfordshire]: Oxford University Press, 1985. Print.

Havelock, Eric, Preface to Plato. Cambridge, Mass.: Harvard University Press, 1963.

Howell, M.L. Manhood and Masculine Identity in William Shakespeare's "The Tragedy of Macbeth". University Press of America, 2008. Print.

Kewes, Paulina, Ian W Archer, and Felicity Heal. The Oxford Handbook Of Holinshed's Chronicles. Oxford: Oxford University Press, 2013. Print.

Kimbrough, Robert. "Macbeth: The Prisoner of Gender." Shakespeare studies. 16 175-190. Web. < https://glocat.geneseo.edu/discovery/openurl?institution=01SUNY_GEN\&rfr_id=info:sid\%252Fprimo .exlibrisgroup.com-bX-Bx\&rfr_id=info:sid\%2Fprimo.exlibrisgroup.com-8350233-

Bx\&rft_val_fmt=info:ofi\%2Ffmt:kev:mtx:\&rft.epage=190\&rft.volume=16\&rft_id=info:doi\%2F\&rft.jtitle= 
Shakespeare\%20studies\&rft.isbn=\&rft.btitle=\&rft.genre=article\&rft.issue=\&rft.auinit1=R\&rft.eisbn=\&rft .aulast=Kimbrough,\%20Robert\&rft.auinit=RM\&rft.spage=175\&rft.au=Kimbrough,\%20Robert, \%20Rober t\%20M\&rft.atitle=Macbeth:\%20The\%20Prisoner\%20of\%20Gender.\&rft_dat=\&rft.issn=0582-

9399\&rft.eissn $=0582-$

9399\&svc_dat=CTO\&u.ignore_date_coverage=true\&vid=01SUNY_GEN:01SUNY_GEN>

Kingsford, Charles Lethbridge. English Historical Literature In The Fifteenth Century. Warsaw: Palala Press, 2018. Print.

La Primaudaye, Pierre de. "The French Academei." Name.umdl.umich.edu. N.p., 1545. Web. 16 Feb. 2021. <http://name.umdl.umich.edu/A05094.0001.001>.

Lander, J. R, and J. B Smallman. Conflict And Stability In Fifteenth-Century England. London: HarperCollins Publishers Ltd, 1987. Print.

Legh, Gerard. Accedens Of Armory. London: Proquest, Eebo Editions, 1568. Print.

Marx, Steven. "Holy War In Henry Fifth." DigitalCommons@CalPoly. N.p., 1995. Web. 16 Jan. 2021. $<$ https://digitalcommons.calpoly.edu/engl_fac/10/>.

Mazzaro, Jerome "Madness and Memory: Shakespeare's HAMLET and KING LEAR," COMPARATIVE

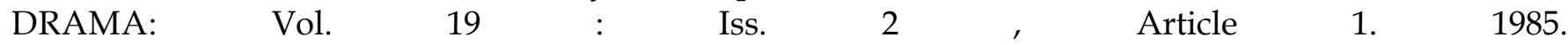
<https://scholarworks.wmich.edu/compdr/vol19/iss2/1>

Muir, Kenneth, Introduction to the Arden King Lear. Cambridge.: Harvard University press, 1959.

Munro, R. "Lady Macbeth: A Psychological Sketch." The Journal of Speculative Philosophy. 21(1).2012:30-36. Print.

Mythologies : Studies in Poetry, Drama and Music. Cambridge : Cambridge University Press, 1994, pp. 44-62.

Nigel, Alexander. "Hamlet And The Art Of Memory." Ur.booksc.eu. N.p., 1968. Web. 11 Feb. 2021. <https://ur.booksc.eu/book/75567691/078ab0>.

Reed, Robert, Bedlam on the Jacobean Stage. Cambridge: Harvard University Press, 1952, pp., 32, 73.

Shakespeare, William et al. The Norton Shakespeare. London: WW Norton, 1997. Print.

Shakespeare, William, and Bernard Groom. Macbeth. Oxford: Oxford University Press, 1995. Print.

Shakespeare, William, and Gary Taylor. Henry V. Oxford: Oxford University Press, 1998. Print.

Shakespeare, William, and J. H Walter. King Henry V. London: Routledge, 1991. Print.

Sidney, Philip, and Forrest G Robinson. An Apology For Poetry. New York: Macmillan Pub. Co., 1985. Print.

Spence, Jonathan D., The Memory Palace of Matteo Ricci. New York: Viking Press, 1984, pp.12-13.

Tipton, Alzada. "The Transformation of the Earl of Essex: Post-Execution Ballads and 'The Phoenix and the Turtle.'" Studies in Philology, vol. 99, no. 1, 2002, pp. 57-80. JSTOR, www.jstor.org/stable/4174719. Accessed 10 Feb 2021.

Tolhurst, Fiona. "Geoffrey of Monmouth's 'Historia Regum Britannie' and the Critics." Arthuriana, vol. 8, no. 4, 1998, pp. 3-11. JSTOR, www.jstor.org/stable/27869396. Accessed 7 March 2021.

Wells, Robin Headlam, Shakespeare on Masculinity. United kingdom: Cambridge University Press, 2000. 
Wright, p. 48. H. Somerville, Madness in Shakespearean Tragedy. London: Richards press,1929.

Yates, Frances, The Art of Memory. Chicago: University of Chicago Press, 1966.

${ }^{1}$ RAHUL KAR, an Assistant Teacher of a Govt. High School is an M.A in English Literature, specializes in POST-COLONIAL INDIAN ENGLISH LITERATURE, pursues interest in Critical Reading and Writing. He is an author of "MISERIES OF 'SECOND SEX', FROM COVERT TO OVERT: RE-READING OF KAMALA DAS' MY STORY (ENTE KATHA) THROUGH THE LENSES OF HER POEMS", published from Trans Steller Journal.Besides that, he has got another published paper from IJARESM, titled Re-rendering of the concept of Narratological Craft, Concretion of Nationalism, Graffiti of vivid Figures, Anti-Imperialistic reactionary attitude, Indo-Anglian-Ness and Adhyatmabada(Spritism): With Special Reference to a re-contextualisation of a Post-Colonial study of R.K. Narayan's The English Teacher(1945).He is neither associated with any research course nor possess any membership affiliation. The author is a CBSE-NET qualifier.

2 SANGEETA SAHA, is an M.A in English literature, she specializes in Indian English Post-Colonial Literature. She hugely purses interest in critical reading and writing though having no research or publication experience nor possesses any membership affiliation. She has two different essays titled as, $A$ Critical Re-Expositioning of Configuring the notions of Diaspora, Schismatical Affray, Trans-bordering, Metaphorization in Title and Chapters and Meta-Narration in method of Penning in Post the Imperial regime in Asia: A Structural, Stylistic and Thematic Re-Cognition of Amitav Ghosh's The Shadow Lines(1988) and Recontextualizing the notions of Nation, Nationalism, History, Narratological Strategy, Undertone of Cinematic Bollywood in the backdrop of (Post)Colonial India: A re-reading of Salman Rushdie's 'Midnight's Children'(1981)published in IJCRT and IJARESM respectively. The author is an NTA-Net qualifier and is a Govt. School Teacher of West Bengal. 